\title{
Pelatihan Pembuatan hand-sanitizer alami dari daun sirih guna mencegah penyebaran Covid- 19 di Nagori Tigaras
}

\author{
Dian Perayanti Sinaga, Joni Wilson Sitopu*, Ika Rosenta Puba, Thiur Dianti Siboro, Sumarni \\ Tridelpina Purba, Irwan Lihardo Hulu, Marlindoaman Saragih, Risjunardi Damanik, Komaru \\ M.Komarul Huda, Salome Rajagukguk, Fenny Mustika Piliang
}

${ }^{1,2,3)}$ Universitas Simalungun

Koresponden email : jwsitopu@gmail.com

\begin{abstract}
Abstrak: Penggunaan Hand sanitizer di kalangan masyarakat ekonomi sudah menjadi gaya hidup. Berbagai produk Antiseptik pembersih tangan atau hand sanitizer merupakan produk pilihan masyarakt saat ini, karena mudah dibawa kemana-mana dan cara pemakaian yang cukup sederhana dan cepat yaitu diteteskan pada telapak tangan kemudian diratakan pada permukaan tangan. Namun biasanya handsanitizer banyak mengandung alkohol dan antiseptik berupa bahan kimia sintetis yang harganya relatif mahal dan sering menimbulkan masalah kesehatan kulit seperti kulit menjadi kering atau terjadi penurunan kelembaban kulit. Oleh karena itu dicari bahan alternatif dengan menggunakan bahan alami yang relatif lebih murah, aman, efektif, dan mudah didapat yaitu dau sirih. Daun sirih adalah salah satu tanaman yang dapat dimanfaatkan sebagai bahan alami pembuatan handsanitize dengan biaya produksi yang murah dimana daun sirih tersebut banyak dijumpai di Nagori Tigaras. Berdasarkan hal tersebut, dipandang perlu menyikapi situasi ini, Dosen Pendidikan FKIP USI memberikan pelatihan pembuatan hansaitizer dari bahan alami daun sirih sehingga dapat menghasilkan hansanitizer yang dapat dimanfaat untuk diri sendiri juga Hansanitizer dari bahan dikemas sehingga produksinya dapat dijual sebagai pendapatan rumah tangga
\end{abstract}

Kata Kunci: Hand-sanitizer, daun sirih, mencegah virus

\section{Pendahuluan}

Ditengah adanya pandemi Virus Corona (covid-19) yang sedang menimpa dunia membuat masyarakat menjadi panik. Mudahnya penyebaran virus corona ini maka sangat diperlukan edukasi kepada masyarakat mengenai pentingnya menjaga pola hidup sehat agar terhindar dari penularan virus tersebut. Pola hidup sehat yang diterapkan dimasyarakat adalah dengan penggunaan masker sebagai cara untuk berjaga jaga, menjaga jarak minimal $1 \mathrm{~m}$, menggunakan sarung tangan dan mencuci setiap hari.(Thalib,2020:31). Kesadaran akan pentingnya menjaga pola hidup bersih dan sehat dengan cara mencuci tangan dengan menggunakan sabun dan air merupakan cara paling efektif dalam membersihkan kotoran pada permukaan kulit dari berbagai mikroorganisme serta virus, namun terkadang mencuci tangan hal yang merepotkan karena tidak semua sudut ruang terdapat air dan sabun. Antiseptik pembersih tangan atau hand sanitizer merupakan produk pilihan masyarakat saat ini, karena mudah dibawa kemana-mana.

Penggunaan Hand sanitizer di kalangan masyarakat ekonomi sudah menjadi gaya hidup. Berbagai produk Hand Sanitizer dapat ditemukan di toko-toko swalayan dengan cara pemakaian yang cukup sederhana dan cepat yaitu diteteskan pada telapak tangan kemudian diratakan pada permukaan tangan.

Hand Sanitizer yang digunakan adalah berbahan aktif alkohol 40-80\%. Alkohol telah digunakan secara luas sebagai obat antiseptik kulit karena mempunyai efek menghambat bakteri. Menurut Foof 
And Drug Administration (FDA), alkohol yang terdapat pada hand-sanitizer memiliki kemampuan aktivitas bakteorisidasi yang baik terhadap bakteri gram positif dan gram negatif sehingga mampu menghilangkan kuman kurang dari 30 detik (suyani, 2013).

Namun biasanya hand-sanitizer banyak mengandung alkohol dan antiseptik berupa bahan kimia sintetis yang harganya relatif mahal dan sering menimbulkan masalah kesehatan kulit seperti kulit menjadi kering atau terjadi penurunan kelembaban kulit. ( Retnosari, 2007). Oleh karena itu dicari bahan alternatif dengan mengunakan bahan alami yang relatif lebih murah, aman, efektif, dan mudah didapat.

Daun sirih adalah salah satu tanaman yang dapat dimanfaatkan sebagai bahan alami pembuatan hand-sanitizer. Secara tradisional biasanya daun sirih digunakan untuk mengobati berbagai jenis penyakit seperti obat pembersih mata, menghilangkan bau badan, mimisan, sariawan, pendarahan gusi, batuk, keputihan dan obat kulit sebagai perawatan untuk kecantikan atau kehalusan kulit dan acara adar istiadat. (Sukriani, 2016:72). Rebusan daun sirih dapat membersihkan mulut (obat kumur) dan untuk membersihkan bagian tubuh lainnya juga digunakan sebagai antiseptik (Mardisiswojo, 1985, anonim,1981).

Minyak Atsiri banyak terkandung dalam daun sirih yang tersusun atas beberapa komposen kimia yang digolongkan sebagai senyawa fenol dan senyawa selain fenol. Senyawa fenol yang menyusun minyak atsiri terdiri dari dua komponen fenol yaitu isomer betel fenol dari kavikol dan eugenol dengan berbagai kombinasi fenol seperti alil piroikatekol, kavibetol, karvakrol, metal eugenol, sineo dan estragol. Senyawa kimia selain fenol terdiri dari kadinen, kariofilen, terpen, terpinen, metal eter, menthon dan seskuiterpen ( dalam Darma, 1985). Sirih sudah dikenal mengandung zat antiseptik yang dapat membunuh bakteri sehingga banyak digunakan sebagai anti bakteri dan anti jamur (Novita,2016) Ekstrak daun sirih telah dikembangkan dalam berbagai produk misalnya pasta gigi, sabun, obat kumur karena daya antiseptiknya.

Tanaman daun sirih banyak tumbuh di Nagori Tigaras, daun sirih tumbuh subur karena tanaman ini mudah merambat dimana saja. Masyarakat Nagori Tigaras telah terbiasa menggunakan daun sirih ini untuk ada acara adat istiadat dan untuk obat tradisional. Dengan pemanfaatan daun sirih yang melimpah di Nagori Tigaras dan kandungan kimia yang terdapat pada ekstrak daun sirih yang dapat digunakan sebagai bahan antiseptik untuk mencegah penyebaran virus maka Dosen FKIP Uuniversitas Simalungun berinisiatif untuk membuat produk berupa hand sanitizer alami dari daun sirih yang mampu membunuh virus, sehingga dapat mengurangi penyebaran virus covid-19 ditengah pandemi saat ini.

\section{Realisasi Kegiatan}

Langkah-langkah kegiatan penyuluhan yang dilakukan oleh dosen Pendidikan Biologi FKIP USI Pematangsiantar di Nagori Tigaras dengan cara mengumpulkan masyarakat yang ada di Nagori Tigaras di Kantor Nagori untuk mengikuti Penyuluhan dan pelatihan pembuatan handsanitizer dari bahan alami daun sirih yang telah terbukti dapat menanggulangi penyebaran virus corona.

\section{Alat, bahan dan cara pembuatan}

Alat

a. Pisau

b. Wadah

c. Wadah masak

d. Gelas

e. Sendok

Bahan

f. Alat penyaring
a. Daun sirih 50 gram
b. Alkohol $100 \mathrm{ml}$ (kadar 70\%)
c. Air $200 \mathrm{ml}$ 


\section{Cara Pembuatan}

a. Siapkan semua alat dan bahan

b. Cuci bersih terlebih dahulu daun sirih

c. Kemudian potong daun sirih menjadi beberapa bagian

d. Kemudian didihkan air bersamaan dengan daun sirih hingga menghasilkan 50\% dari $200 \mathrm{ml}$

e. Lalu tirisi air daun sirih , dan tunggu sampai air tirisannya dingin

f. Setelah dingin, tambahkan alkohol pada air daun sirih tersebut.

g. Lalu kemas ke dalam botol dan berikan label nya

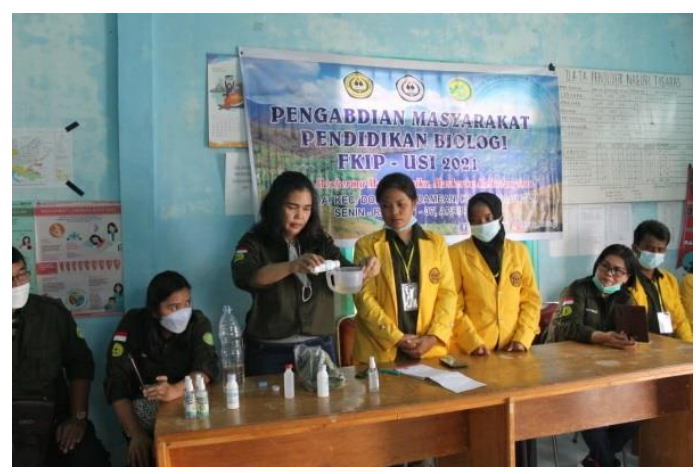

Gambar 1. Pembuatan hand-sanitizer pada masyarakat Nagori Tigadolok

\section{Hasil}

Hasil kegiatan pengabdian masyarakat berisi tentang laporan kegiatan pengabdian masyarakat yang dinarasikan secara ringkas dalam beberapa paragraf. Penjabaran hasil kegiatan pengabdian masyarakat dapat dibantu dengan gambar, tabel, diagram maupun grafik. Pemaparan gambar, tabel, diagram maupun grafik harus dibuat dengan sejelas mungkin, agar mudah dibaca dan dipahami. Berikut contoh pemaparan tabel dan gambar beserta keterangannya :
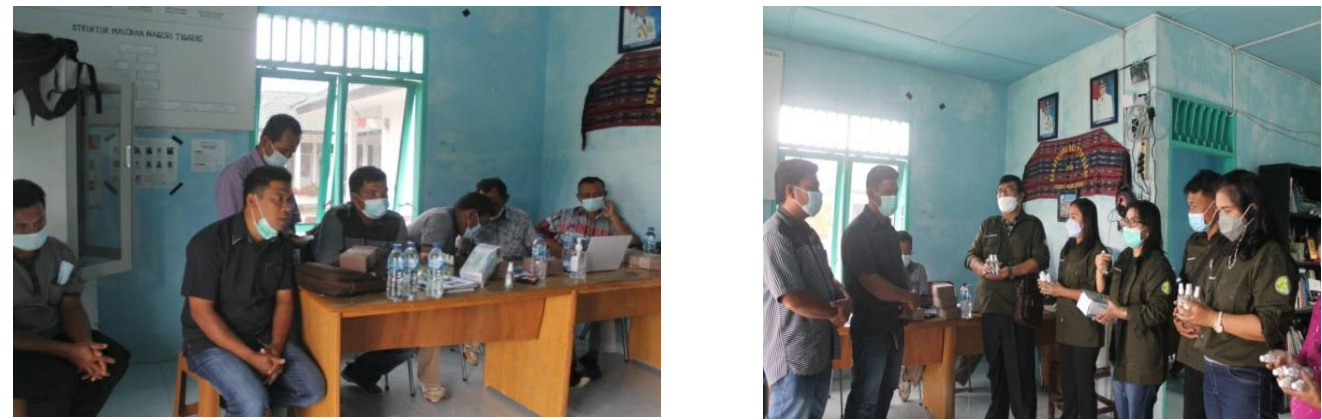

Gambar 2. Membagikan Hand Sanitizer $n$ Masker kepada Kepala Desa dan

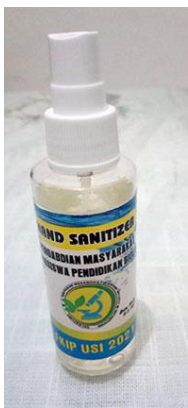

Gambar 3. Produk Hasil jadi hand-sanitizer 


\section{Kesimpulan}

Kegiatan Pengabdian Kepada Masyarakat di Nagori Tigaras yang dilakukan oleh Dosen Pendidikan Biologi FKIP USI Pematangsiantar dalam penanggulangan penyebaran virus corona berupa pelatihan pembuatan handsanitizer alami dengan pemberian materi melalui ceramah dan praktik. Handsanitizer digunakan untuk mengefektikan waktu jika terburu buru mencuci tangan karena tidak memungkinkan menggunakan air. Bahan yang digunakan merupakan bahan alami yang mudah didapatkan di Nagori Tigaras sehingga biaya produksi lebih murah. Alat yang digunakan juga mudah dicari, serta cara pembuatan yang mudah sangat membantu masyarakat untuk membuat hand sanitizer alami sendiri. Selain memanfaatkan bahan alami yang ada disekitar untuk digunakan sendiri, produk handsanitizer ini juga bida dijadikan produk yang dapat dijual kembali.

\section{Daftar Pustaka}

Diana, A. (2021) Pengaruh Desiminasi Dokter Kecil tentang Penggunaan Hanndsanitizer dan Spray terhadap Penurunan Angka Kuman Tangan Sisiwa sda Demakijo Gamping

Isandiartuti,D,.\&Sari,R.2006.Studi Efektivitas Sediaan Gel Antiseptik Tangan Ekstrak Daun Sirih (Piper Betle Linn.) Antiseptic Activity Evaluation of Piper Leave FromPiper Betle Linn Extract in Hand Gel Antiseptic Preparation, Majalah Farmasi Indonesia, 17(4):163-169

Prabowo, W.C., Widayat,W,.\&Defriana, S.(2018),Formulasi infusan Daun Sirih Merah(Piper Crocatum) sebagai Gel Antiseptik Tangan. Jurnal Sains Dan Kesehatan 1(10). 525-530

Thalib,Abdul.2020. Herbal Potensial Sebagai Hand Sanitizer di Indonesi: Literatur Review. Pasapua Health Jornal.2(1):120 